\title{
Morphological changes in the rat small intestine in response to riboflavin depletion
}

\author{
B Y E. A. WILLIAMS AND H. J. POWERS* \\ University Department of Paediatrics, Sheffeld Children's Hospital, Western Bank, \\ Sheffield $\mathrm{S} 10 \mathrm{2TH}$ \\ AND R. D. E. RUMSEY \\ Department of Biomedical Science, University of Sheffield, S10 2TH
}

(Received 28 April 1994-Accepted 14 June 1994)

\begin{abstract}
Female Wistar rats were weaned onto a diet deficient in riboflavin and compared with weight-matched and $a d$ lib.-fed controls. The effects of riboflavin deficiency on villus morphometry and enterocyte number on the villi in the upper small intestine were studied. Riboflavin depletion was associated with increased villus length and a proportional increase in the number of cell positions along the villi. The total DNA, RNA and protein contents in the intestinal mucosa were not significantly different between any of the groups. Villus hypertrophy in the absence of increased cell number in the small intestine suggests that villus number may be reduced in riboflavin deficiency. Riboflavin deficiency did not influence the number of mucus-producing goblet cells or the amount of mucosal glycoprotein in the small intestine. Impaired production of mucus appeared not to be involved in the structural and functional changes seen in riboflavin deficiency.
\end{abstract}

Riboflavin: Rat: Villus morphology

There is substantial evidence from studies in riboflavin-deficient human populations (Powers et al. 1983b; Fairweather-Tait et al. 1992) and in small animals (Powers \& Bates, 1984; Powers et al. 1983a, 1988) that riboflavin deficiency influences Fe metabolism. Some interest has been shown in the possible involvement of flavins in mitochondrial and cytoplasmic enzymes able to reduce and thereby mobilize ferritin Fe (Powers et al. 1983a; Powers, 1986). Activities of these enzymes are reduced in in vitro preparations of various tissues from rats depleted of riboflavin. An involvement of riboflavin in the reductive mobilization of ferritin $\mathrm{Fe}$ implicates riboflavin in several aspects of $\mathrm{Fe}$ metabolism, including absorption and hepatic Fe release. Riboflavin deficiency has been shown not only to impair Fe absorption but also to enhance gastrointestinal Fe loss (Powers et al. 1991) and attention has focused more recently on the effects of riboflavin deficiency on the structure and function of the small intestine.

Riboflavin deficiency in the weanling rat is associated with an increased crypt depth and an increased crypt-cell production rate in the upper small intestine (Powers et al. 1993) and it was hypothesized that an enhanced turnover of mucosal epithelial cells of the small intestine may be responsible for the increased rate of loss of Fe. Villus structure in the duodenum of riboflavin-deficient weanling Wistar rats was studied in an attempt to quantify further the gastrointestinal changes in response to riboflavin depletion. Scanning electron microscopy suggested that mucus production may be reduced in the riboflavindepleted state (Williams et al. 1993). This was investigated further by measuring the

$$
\text { * For reprints. }
$$


number of mucus-producing goblet cells in the upper small intestine and the quantity of glycoprotein in the small-intestinal mucosa.

\section{METHODS AND MATERIALS}

Fifty female weanling Wistar rats (Sheffield strain) were bred and weaned in a pathogenfree environment. The rats had body weights of between 28 and $61 \mathrm{~g}$ and were individually housed in wire-bottomed cages and weaned onto their appropriate diet on days 21-23 of life. The rats were divided into three dietary groups: riboflavin deficient (RD), weight matched (WM) and ad lib. (AL). Twenty rats were randomly allocated to the RD group and twenty, matched by weight, allocated to the WM group. The RD group received a basal diet $(\mathrm{g} / \mathrm{kg})$ : arachis oil 30 , sucrose 700 , casein 200 (containing $0.52 \mathrm{mg}$ riboflavin $/ \mathrm{kg}$ diet), a vitamin mixture (riboflavin deficient) and Briggs salt mixture (Seaford Laboratories, Seaford, East Sussex). Animals allocated to the WM group received the basal diet supplemented with riboflavin $(15 \mathrm{mg} / \mathrm{kg})$, which constituted a 'complete diet'. Feed consumption of each animal was controlled so that the rate of growth was equal to that of its riboflavin-depleted partner. Ten animals were fed ad lib. on the complete diet. After $14 \mathrm{~d}$ the availability of the feed was restricted to the period between 09.00 and 17.00 hours, for all rats. The rats were maintained on their diets for 5 weeks.

Approximately $100 \mu \mathrm{l}$ blood was collected from a branch of the saphenous vein into a heparinized tube on days 0 and 18 of the experiment. Erythrocytes were separated, washed in isotonic saline $(9 \mathrm{~g} \mathrm{NaCl} / 1)$, and stored at $-20^{\circ}$ in distilled water $(1: 3)$ for subsequent measurement of riboflavin status. Riboflavin status, which was expressed in terms of the activation coefficient for the FAD-dependent enzyme erythrocyte glutathione reductase (EC 1 6.4.2), was measured spectrophotometrically using the Cobas Bio Autoanalyser (Powers et al. $1983 \mathrm{~b}$ ). An 'in house' quality control sample was included with each batch of samples analysed.

After 5 weeks the rats were anaesthetized by injection of $0.01 \mathrm{ml}$ ketamine-xylazine mixture $(2: 1, \mathrm{v} / \mathrm{v}) / \mathrm{g}$ body weight and killed by exsanguination. The liver was removed for the measurement of liver flavins using fluorimetry (Bessey et al. 1949). The small intestine was carefully dissected from the abdominal cavity, weighed and its length measured. Two $10 \mathrm{~mm}$ sections of duodenum were removed: the first was fixed in glutaraldehyde for scanning electron microscopy and the second fixed in ethanol-acetic acid $(75: 25, \mathrm{v} / \mathrm{v})$ for $24 \mathrm{~h}$ and then stored in $700 \mathrm{ml} / 1$ ethanol for subsequent histological sectioning. The remainder of the small intestine was frozen at $-20^{\circ}$ for nucleic acid and protein estimations.

The mucosa of the small intestine was scraped away from the submucosa and muscularis (Williamson et al. 1978), for the measurement of nucleic acids and glycoprotein. DNA and RNA were measured by a modification of a method described by Munro \& Fleck (1966). Protein content was measured using the Lowry assay (Lowry et al. 1951) and the glycoprotein by a colorimetic assay described by Mantle \& Allen (1978).

Electron micrographs of the surface of the mucosa were studied qualitatively. Histological sections cut and stained with haematoxylin and eosin and alcian blue were used to determine villus height, enterocyte number and goblet-cell number on maximumheight villus samples.

\section{Statistical analysis}

A two-way analysis of variance was performed to investigate the effects of time and diet on the erythrocyte glutathione reductase activation coefficient (EGRAC). A one-way analysis of variance was used to establish whether diet had an influence on any of the other variables 
Table 1. Riboflavin status of riboflavin-deficient $(R D)$ rats, weight-matched $(W M)$ controls and ad lib.-fed controls after 5 weeks on their experimental diets*

(Mean values with their standard errors)

\begin{tabular}{|c|c|c|c|c|c|c|c|}
\hline & \multirow[b]{2}{*}{$n$} & \multicolumn{2}{|c|}{ EGRAC } & \multicolumn{2}{|c|}{$\begin{array}{l}\text { Liver FAD } \\
(\mu \mathrm{g} / \mathrm{g} \text { wet wt) }\end{array}$} & \multicolumn{2}{|c|}{$\begin{array}{c}\text { Liver FMN + } \\
\text { riboflavin } \\
(\mu \mathrm{g} / \mathrm{g} \text { wet wt) }\end{array}$} \\
\hline & & Mean & SEM & Mean & SEM & Mean & SEM \\
\hline RD & 20 & $1 \cdot 85^{\mathrm{a}}$ & 0.05 & $14 \cdot 5^{\mathrm{a}}$ & 0.65 & $3 \cdot 5^{\mathrm{a}}$ & 0.26 \\
\hline WM & 20 & $1 \cdot 19^{\mathrm{b}}$ & 0.04 & $22 \cdot 6^{\mathrm{b}}$ & 0.75 & $6.8^{\mathrm{b}}$ & 0.29 \\
\hline Ad lib. & 9 & $1 \cdot 19^{\mathrm{b}}$ & 0.04 & $17 \cdot 6^{\mathrm{C}}$ & 1.02 & $8 \cdot 5^{\mathrm{c}}$ & $0 \cdot 31$ \\
\hline \multicolumn{2}{|c|}{ Statistical significance } & $<0.001$ & & $<0.001$ & & $<0.001$ & \\
\hline
\end{tabular}

EGRAC, erythrocyte glutathione reductase activity coefficient.

abc Values with unlike superscripts in the same column were significantly different, $P<0.01$ (Student's $t$ test).

* For details of diets and procedures see pp. 142-143.

$\dagger$ Significance of the value for overall $F$ ratio in one-way analysis of variance.

measured (villus height, villus column-cell number, total DNA, RNA, protein and glycoprotein of the small-intestinal mucosa). Where an influence was identified an unpaired Student's $t$ test was applied.

RESULTS

Table 1 shows the riboflavin status of the rats after 5 weeks on the experimental diets. The conventional cut-off point of 1.3 for EGRAC was used to indicate a biochemical deficiency of riboflavin (Glatzle et al. 1970). A two-way analysis of variance revealed significant effects of both diet and time on riboflavin status. Rats fed on a riboflavin-depleted diet had a significantly greater EGRAC value than either of the control groups from day 18 onwards.

A one-way analysis of variance demonstrated an effect of diet on liver flavins. The Student's $t$ test revealed a significant reduction in liver flavins in the RD group compared with both WM $(P<0.001)$ and AL groups $(P<0.001)$. Liver flavins correlated well with EGRAC values $(r 0.76, P<0.001)$.

Table 2 shows the mean body weights of the rats at the start and end of the experiment together with the average feed consumption and growth rate. There was no significant difference between the body weights of any of the groups at the start of the experiment. The AL rats had a significantly higher final body weight than either WM $(P<0.02)$ or RD $(P<0.02)$ rats. The average daily feed consumption was higher in the AL-fed animals than either the WM $(P<0.05)$ or RD $(P<0.05)$ and the RD feed intake was significantly higher than that of the WM $(P<0.05)$. The efficiency of feed utilization (weight gain $/ \mathrm{g}$ diet) was not different between the groups.

A one-way analysis of variance showed no effect of diet on length, weight or mucosal weight of the small intestine. However, there was a close association between final body weight of the rat and gut weight $(r 0.66, P<0.001)$ and between gastrointestinal tract weight and mucosal weight $(r 0.90, P<0.001)$.

Table 3 shows the effect of riboflavin depletion on villus structure. There was a significant increase in the villus height and the number of cells per villus column in the RD group compared with both the AL and WM controls. There was no significant difference between the number of goblet cells nor in the goblet cells: total cells ratio in a single villus section. 
Table 2. Effect of diet on feed consumption, body weight, and indicators of growth of the small intestine $(S I)$ in riboflavin-deficient rats, weight-matched controls and ad lib.-fed controls*

(Mean values with their standard errors)

\begin{tabular}{|c|c|c|c|c|c|c|c|}
\hline & \multicolumn{2}{|c|}{$\begin{array}{l}\text { Riboflavin-deficient } \\
(n 20)\end{array}$} & \multicolumn{2}{|c|}{$\begin{array}{l}\text { Weight-matched } \\
\qquad(n \text { 20) }\end{array}$} & \multicolumn{2}{|c|}{$\begin{array}{l}\text { Ad lib. } \\
(n 9)\end{array}$} & \multirow{2}{*}{$\begin{array}{c}\text { Statistical } \\
\text { significance } \\
\text { of difference } \dagger \text { : } \\
P=\end{array}$} \\
\hline & Mean & SEM & Mean & SEM & Mean & SEM & \\
\hline Initial body wt $(\mathrm{g})$ & $43 \cdot 8$ & $2 \cdot 22$ & $41 \cdot 6$ & $2 \cdot 25$ & $43 \cdot 2$ & 3.67 & 0.418 \\
\hline Final wt $(\mathrm{g})$ & $117 \cdot 4^{\mathrm{a}}$ & $6 \cdot 10$ & $118 \cdot 9^{a}$ & 4.93 & $128 \cdot 3^{b}$ & $7 \cdot 07$ & 0.019 \\
\hline Feed intake $(\mathrm{g} / \mathrm{d})$ & $11 \cdot 6^{\mathrm{a}}$ & 0.22 & $10 \cdot 7^{b}$ & 2.59 & $12 \cdot 7^{\mathrm{c}}$ & 0.21 & $<0.001$ \\
\hline Wt gain ( $\mathrm{g} / \mathrm{g}$ diet $)$ & $0 \cdot 19$ & 0.005 & 0.19 & 0.003 & 0.19 & 0.006 & 0.597 \\
\hline SI wt $(\mathrm{g})$ & $5 \cdot 7$ & 0.23 & $5 \cdot 4$ & $0 \cdot 15$ & $6 \cdot 4$ & $0 \cdot 41$ & 0.054 \\
\hline Mucosal wt (g) & 3.9 & $0 \cdot 19$ & $4 \cdot 0$ & $2 \cdot 76$ & $4 \cdot 2$ & $0-31$ & 0.316 \\
\hline SI length (mm) & 812 & $26 \cdot 8$ & 829 & $27 \cdot 6$ & 875 & $46 \cdot 3$ & 0.471 \\
\hline
\end{tabular}

abc Values with unlike superscripts in the same row were significantly different, $P<0.05$ (Student's $t$ test).

* For details of diets and procedures, see pp. 142-143.

$\dagger$ Significance of the value for overall $F$ ratio in one-way analysis of variance.

Table 3. Villus structure and goblet-cell number in the small intestine of rats fed on a riboflavin-deficient diet and in weight-matched controls and ad lib.-fed controls*

(Mean values with their standard errors)

\begin{tabular}{|c|c|c|c|c|c|c|c|}
\hline & \multicolumn{2}{|c|}{$\begin{array}{l}\text { Riboflavin-deficient } \\
(\text { (n 20) }\end{array}$} & \multicolumn{2}{|c|}{$\begin{array}{l}\text { Weight-matched } \\
\qquad(n \text { 20) }\end{array}$} & \multicolumn{2}{|c|}{$\begin{array}{l}\text { Ad lib. } \\
(n 9)\end{array}$} & \multirow{2}{*}{$\begin{array}{c}\text { Statistical } \\
\text { significance } \\
\text { of difference } \\
P=\end{array}$} \\
\hline & Mean & SEM & Mean & SEM & Mean & SEM & \\
\hline Villus height ( $\mu \mathrm{m})$ & $622^{\mathrm{a}}$ & 25 & $532^{b}$ & 21 & $549^{b}$ & 42 & 0.046 \\
\hline $\begin{array}{l}\text { Cell positions/villus } \\
\text { column }\end{array}$ & $111^{\mathrm{a}}$ & $3 \cdot 0$ & $99^{\mathrm{b}}$ & $2 \cdot 1$ & $99^{b}$ & $3 \cdot 8$ & 0.008 \\
\hline $\begin{array}{l}\text { Goblet cells/villus } \\
\text { column }\end{array}$ & 17 & 0.8 & 16 & 0.9 & 18 & $1 \cdot 24$ & 0.519 \\
\hline $\begin{array}{l}\text { Goblet cells/cell } \\
\text { position }\end{array}$ & 0.2 & $0 \cdot 01$ & $0 \cdot 2$ & 0.01 & 0.2 & 0.01 & 0.223 \\
\hline
\end{tabular}

ab Values with unlike superscripts within a row were significantly different, $P<0.05$ (Student's $t$ test).

* For details of diets and procedures see pp. 142-143.

$\uparrow$ Significance of the value for overall $F$ ratio in one-way analysis of variance.

Table 4 shows the effects of riboflavin depletion on total mucosal DNA content of the small intestine. RNA, glycoprotein and protein contents are expressed as $\mathrm{mg} / \mathrm{mg}$ mucosal DNA. One-way analysis of variance revealed no effects of riboflavin status on these variables.

\section{DISCUSSION}

In the present experiment, EGRAC values correlated well with concentrations of liver flavins, confirming the chronic nature of the riboflavin deficiency. Such an association may not be expected in an acutely deficient animal (Prentice \& Bates, 1981a). Riboflavin deficiency was established within $18 \mathrm{~d}$ on the depleted diet. Riboflavin depletion in the 
Table 4. Effects of riboflavin deficiency on total mucosal DNA (mg) and on the RNA:DNA, glycoprotein: $D N A$ and protein: $D N A$ ratios $(\mathrm{mg} / \mathrm{mg})$ of the small-intestinal mucosa in the rat $^{*}$

(Mean values with their standard errors)

\begin{tabular}{|c|c|c|c|c|c|c|c|}
\hline & \multicolumn{2}{|c|}{$\begin{array}{l}\text { Riboflavin-deficient } \\
(\text { ( } 20)\end{array}$} & \multicolumn{2}{|c|}{$\begin{array}{l}\text { Weight-matched } \\
(n \text { 20) }\end{array}$} & \multicolumn{2}{|c|}{$\begin{array}{c}\text { Ad lib. } \\
(n 9)\end{array}$} & \multirow{2}{*}{$\begin{array}{c}\text { Statistical } \\
\text { significance } \\
\text { of difference } \dagger \\
P=\end{array}$} \\
\hline & Mean & SEM & Mean & SEM & Mean & SEM & \\
\hline Total mucosal DNA (mg) & $12 \cdot 3$ & 0.66 & $12 \cdot 7$ & 0.64 & $12 \cdot 0$ & 0.75 & 0.809 \\
\hline RNA:DNA & $1 \cdot 12$ & 0.050 & $1 \cdot 14$ & 0.084 & $1 \cdot 07$ & 0.093 & 0.775 \\
\hline Glycoprotein:DNA & 21.8 & $2 \cdot 06$ & $20 \cdot 3$ & 1.42 & $23 \cdot 4$ & $2 \cdot 20$ & 0.578 \\
\hline Protein:DNA & $65 \cdot 6$ & $3 \cdot 55$ & $60 \cdot 0$ & $3 \cdot 27$ & $64 \cdot 6$ & $2 \cdot 48$ & 0.443 \\
\hline
\end{tabular}

* For details of diets and procedures see pp. 142-143.

$\dagger$ Significance of the value for overall $F$ ratio in one-way analysis of variance.

weanling Wistar rat was not associated with a reduction in growth rate as previously reported in the Norwegian Hooded strain (Prentice \& Bates, $1981 b$ ).

The deficient animals showed an increased villus height in the upper small intestine compared with weight-matched controls. There was no significant difference between the villus height of the WM and AL groups. This strongly suggests that riboflavin depletion produces villus hypertrophy.

Riboflavin depletion was associated with a significant increase in the number of cells on a single villus column, suggesting that the increased villus height was produced by an increased cell number. Despite the increase in villus height and villus cellularity in the riboflavin-deficient rats, total mucosal DNA content of the small intestine was unchanged. This finding suggests that the total mucosal-cell population is not elevated in riboflavin deficiency. However, since crypt depth (Powers et al. 1993) together with villus height are increased, one possible explanation for this apparent anomaly is that riboflavin deficiency reduces the total number of villi produced during post-weaning development. This is a particularly intriguing possibility since villus number is thought to be fixed during the later stages of adolescent development (Goss, 1966). Any effects of riboflavin depletion on this variable in the critical stages of gastrointestinal development may therefore be irreversible.

In an earlier study electron micrographs of the small intestine from riboflavin-deficient animals appeared to be devoid of mucus, in contrast with weight-matched control animals (Williams et al. 1993). We investigated the amount of glycoprotein and the number of mucus-producing goblet cells along the villi and found no significant difference in the number of goblet cells or in the quantity of glycoprotein contained within the small intestine of the RD group compared with the WM and AL groups. Similarly, electron micrographs did not reveal any gross difference in the quantity of mucosal covering. Mucus production appears to be a response to food in the small intestine, and the apparent failure of the RD animals to produce mucus as described previously, probably reflected a longer period of fasting than the control animals in that study.

The present experiment has served to quantify further the structural changes of the small intestine in response to riboflavin deficiency. We have found a significant hypertrophy of the villi and a significant increase in the number of cells per villus column. These findings are compatible with those of Powers et al. (1993) who reported a two-fold increase in the rate of crypt-cell production in riboflavin deficiency. Despite the increase in the number of crypt and villus cells the total number of mucosal cells remains unchanged, which raises 
questions about the size of the villus population. Studies to characterize further the effects of riboflavin deficiency at weaning on the structure and function of the small intestine are in progress.

This work was supported by The Wellcome Trust $(035705 / Z)$.

\section{REFERENCES}

Bessey, O. A., Lowry, O. H. \& Love, R. H. (1949). The fluorimetric measurement of the nucleotides of riboflavin and their concentration in tissues. Journal of Biological Chemistry 180, 755-769.

Fairweather-Tait, S. J., Powers, H. J., Minski, M. J., Whitehead, J. \& Downes, R. (1992). Riboflavin deficiency and iron absorption in adult Gambian men. Annals of Nutrition and Metabolism 36, 3440.

Glatzle, D. H., Korner, W. F., Christeller, S. \& Wiss, O. (1970). Method for the detection of a biochemical riboflavin deficiency. International Journal for Vitamin and Nutrition Research 40, 166-183.

Goss, R. J. (1966). Hypertrophy versus hyperplasia. Science 153, 1615-1620.

Lowry, O. H., Rosebrough, N. J., Farr, A. \& Randali, R. J. (1951). Protein measurement with the Folin phenol reagent. Journal of Biological Chemistry 193, 265-275.

Mantle, M. \& Allen, A. (1978). A colorimetric assay for glycoproteins based on the periodic acid/schiff stain. Biochemical Society Transactions 6, 607-609.

Munro, H. N. \& Fleck, A. (1966). The determination of nucleic acids. In Methods of Biochemical Analysis, vol. 5, pp. 113-176 [D. Glick, editor]. New York: John Wiley.

Powers, H. J. (1986). Investigation into the relative effects of riboflavin deprivation on iron economy in the weanling rat and the adult. Annals of Nutrition and Metabolism 30, 308-315.

Powers, H. J. \& Bates, C. J. (1984). Effects of pregnancy and riboflavin deficiency on some aspects of iron metabolism in rats. International Journal for Vitamin and Nutrition Research 54, 179-183.

Powers, H. J., Bates, C. J. \& Duerden, J. M. (1983a). Effects of riboflavin deficiency on some aspects of iron metabolism. International Journal for Vitamin and Nutrition Research 53, 371-376.

Powers, H. J., Bates, C. J., Prentice, A. M., Lamb, W. H., Jepson, M. \& Bowman, H. (1983b). The relative effectiveness of iron and iron with riboflavin in correcting a microcytic anaemia in men and children in rural Gambia. Human Nutrition: Clinical Nutrition 37C, 413-425.

Powers, H. J., Weaver, L. T., Austin, S. \& Beresford, J. K. (1993). A proposed intestinal mechanism for the effect of riboflavin deficiency on iron loss in the rat. British Journal of Nutrition 69, 553-561.

Powers, H. J., Weaver, L. T., Austin, S., Wright, A. J. A. \& Fairweather-Tait, S. J. (1991). Riboflavin deficiency in the rat: effects on iron utilization and loss. British Journal of Nutrition 65, 487-496.

Powers, H. J., Wright, A. J. A. \& Fairweather-Tait, S. J. (1988). The effect of riboflavin deficiency in rats on the absorption and distribution of iron. British Journal of Nutrition 59, 381-387.

Prentice, A. M. \& Bates, C. J. (1981 a). A biochemical evaluation of the erythrocyte glutathione reductase test for riboflavin status: dose-response relationship in chronic marginal deficiency. British Journal of Nutrition $\mathbf{4 5}$, $54-65$.

Prentice, A. M. \& Bates, C. J. (1981 b). A biochemical evaluation of the erythrocyte glutathione reductase test for riboflavin status: rate and specificity of response in acute riboflavin deficiency. British Journal of Nutrition 45, $37-53$.

Williams, E. A., Rumsey, R. D. E. \& Powers, H. J. (1993). Effects of feeding a riboflavin-depleted diet on the morphometry of the small intestine of the weanling rat. Proceedings of the Nutrition Society 52, 320A.

Williamson, R. C. N., Chir, M., Bucnholtz, T. W. \& Malt, R. A. (1978). Humoral stimulation of cell proliferation in small bowel after transection and resection in rats. Gastroenterology $75,249-254$. 